\title{
Climate change and transdisciplinary science: problematizing the integration imperative
}

\author{
Nicole Lisa Klenk, Katie Meehan
}

\begin{abstract}
Version Post-print/accepted manuscript
Citation Klenk, N., \& Meehan, K. (2015). Climate change and transdisciplinary

(published version) science: Problematizing the integration imperative. Environmental Science \& Policy, 54, 160-167. https://doi.org/10.1016/i.envsci.2015.05.017

\section{Copyright/License}

(c) (i) $\odot$ This work is licensed under the Creative Commons

BY NG ND Attribution-NonCommercial-NoDerivatives 4.0

International License. To view a copy of this license, visit

http://creativecommons.org/licenses/by-nc-nd/4.0/.
\end{abstract}

How to cite TSpace items

\begin{abstract}
Always cite the published version, so the author(s) will receive recognition through services that track citation counts, e.g. Scopus. If you need to cite the page number of the author manuscript from TSpace because you cannot access the published version, then cite the TSpace version in addition to the published version using the permanent URI (handle) found on the record page.
\end{abstract}

This article was made openly accessible by $U$ of $T$ Faculty. Please tell us how this access benefits you. Your story matters. 


\title{
Climate change and transdisciplinary science: problematizing the integration imperative
}

\author{
Nicole Lisa Klenk ${ }^{a^{*}}$ and Katie Meehan ${ }^{b}$ \\ ${ }^{a}$ (N.L.Klenk) Departments of Physical and Environmental Sciences and Political \\ Science, University of Toronto Scarborough, 1265 Military Trail, Toronto, Ontario, \\ M1C1A4, Canada, Phone +1 4162085089 \\ ${ }^{\mathrm{b}}$ (K. Meehan) Department of Geography, University of Oregon, Eugene, USA, 97403- \\ 1251 \\ Email: meehan@uoregon.edu \\ "Corresponding author
}

\begin{abstract}
In this article we critically examine the 'integration imperative' in transdisciplinary environmental science and build on social constructivist and political theories to suggest alternative approaches of knowledge co-production in transdisciplinary settings. Our argument builds upon a body of literature in social studies of science to cull insights about knowledge co-production, social learning, and the ecology of team science, particularly as it relates to climate change adaptation. Couched in this transdisciplinary literature, we demonstrate, is the assumption that integration necessarily can and should be a regulative ideal. We critique this assumption by examining the 'messy' politics of achieving consensus among radically different, and sometimes irreconcilable, ways of knowing. We argue that the integration imperative conceals the friction, antagonism, and power inherent in knowledge co-production, which in turn can exclude innovative and experimental ways of understanding and adapting to climate change. By way of conclusion, the final section explores three alternative models of knowledge co-production - triangulation, the multiple evidence based approach, and scenario building - and illustrates their application in the context of transdisciplinary research in climate change adaptation in the arctic, focusing on alternative means of cross-boundary engagement with indigenous ways of knowing.
\end{abstract}

Keywords: climate change adaptation; experimentation; triangulation; multiple evidence base approach; scenario building; knowledge co-production; futures research; ontological politics

\section{Introduction}

To address complex societal and environmental issues such as climate change adaptation, new knowledge production models have been proposed to transcend disciplinary and institutional boundaries. Foremost among these is the notion of 'transdisciplinarity,' which has come to represent an idealization of how scientists 'should work' with the diversity of actors $/$ stakeholders affected by environmental issues (Boon et al., 2014; Hadorn et al., 2006; Lynch et al., 2008; Romero-Lankao et al., 2013). By definition, 
transdisciplinarity is understood as a reflexive, integrative, method-driven approach aimed at producing normative knowledge and policy-relevant solutions for societal problems like climate change (Hadorn et al., 2010; Lang et al., 2012). At the core of transdisciplinarity lies integration: the desire to assimilate heterogeneous knowledge (via data, analysis, or claims) through processes of co-production. Ideally, integration occurs on several levels: framing the problem, managing the project, including team members and stakeholders, wrangling data, synthesizing results, and applying insights (Groß and Stauffacher, 2014; Lang et al., 2012). Because climate science projects are often positioned at the confluence of science, policy, and practice, inclusion of different stakeholders and disciplines in knowledge production is often a high priority (Boon et al., 2014). As the argument goes, effective adaptation to climate change requires informed policy making, which in turn will require research paradigms to evolve toward an integration of natural and social science approaches and local knowledge (Ayre and Nettle, 2015; Lynch et al., 2008).

At the same time, this blurring of disciplinary lines and the involvement of nonscientists in processes of societal problem-solving raises important questions about the politics of knowledge production, which may ultimately place limits on the degree to which transdisciplinarity effectively empowers society to confront these issues. If climate change science is the work of composition (Latour, 2014), which involves mobilizing and translating different knowledge systems which do not necessarily share the same ontology of Western science (Descola, 2005), then what does it mean to 'integrate' different knowledges in transdisciplinary settings? Drawing together three specific theories-Bruno Latour's $(2005 ; 2010)$ compositionalist theory of science, Chantal Mouffe's (2005) notion of the 'political', and John Law (2004) and Annemarie Mol's (1999, 2002) 'ontological politics'—we critically examine the 'integration imperative' in transdisciplinary environmental science and then suggest alternative approaches of knowledge co-production in transdisciplinary settings.

Our argument builds upon a body of literature in social studies of science to cull insights about knowledge co-production, social learning, and the ecology of team science, particularly as it relates to climate change adaptation. Couched in the transdisciplinary literature, we demonstrate, is the assumption that integration necessarily can and should be a regulative ideal. Next, we critique this assumption by drawing upon social constructivist and political theories that examine the 'messy' politics of achieving consensus among radically different, and sometimes irreconcilable, ways of knowing. We argue that the integration imperative conceals the friction, antagonism, and power inherent in knowledge co-production, which in turn can exclude innovative and experimental ways of understanding and adapting to climate change (see also Castree et al, 2014). By way of conclusion, the final section explores three alternative models of knowledge co-production - triangulation, the multiple evidence based approach, and scenario building - and illustrate their potential use and implications for transdisciplinary environmental science.

The essay is situated in the context of climate change adaptation, a field increasingly characterized by transdisciplinary discourse and methodological experimentation (Ayre and Nettle, 2015; Kerstin and Barth, 2014; Serrao-Neumann et al., 2015; Romero-Lankao et al., 2013). Adaptation takes place at a number of scales, from local to global; thus integrating knowledge and producing policy-relevant solutions are 
seen as particularly urgent (Adger et al., 2005; Dilling and Lemos, 2011). In theory, the complexities of climate change adaption demand relevant knowledge from a range of disciplines and perspectives, and application that bridges the science-policy gap (Hegger et al., 2012; Serrao-Neumann et al., 2014). As we explain in the next section, research on transdisciplinarity reveals several common factors and patterns that have made it an attractive model for investigating climate change adaptation, despite practical and epistemological challenges.

\section{The science of transdisciplinary science}

Scientific work is heterogeneous, requiring many different actors and viewpoints; yet it also requires convergence and cooperation in order to produce generalizable findings and a univocal product (Star and Griesemer, 1989). As a research paradigm, transdisciplinarity emerged in the 1970s as a top-down approach to implementing systems thinking, and was later adopted by so-called 'post-normal' scientists as a bottomup approach to steer science toward expanded epistemic communities of scientists and non-scientists working together to address complex societal problems (Hirsch Hadorn et al, 2006). Transdisciplinarity is also common to public-private collaborative research networks, funded, mandated and monitored by governments (i.e. university-governmentindustry research or 'triple-helix' networks), which have become commonplace in regional, national and international systems of innovation and science policy (Etzkowitz and Leydesdorff, 2000). These collaborative arrangements are often characterized by a 'mode-2' approach to knowledge co-production: research conducted with knowledge users and/or stakeholders through applied projects intended to inform and spur socioeconomic development (Gibbons et al., 1994).

While transdisciplinarity is not yet considered 'mainstream' science and struggles to receive long-term support from funding organizations (Lawrence, 2014; Lyall et al., 2013), its allure for climate science lies in its promise of balancing epistemologicaldisciplinary heterogeneity and broader demands for knowledge convergence around climate action (Boon et al., 2014). For transdisciplinary science to influence policy it must be credible (involving the adequacy of evidence and arguments); salient (relevant to needs of decision makers); and legitimate (production of knowledge is respectful, unbiased, and fair) (Cash et al., 2003).

A review of the transdisciplinarity literature reveals critical procedural and epistemological factors that are thought to facilitate the co-production of such valid, policy-relevant knowledge in methodologically robust ways. Areas of consensus focus on the structural, institutional, behavioral, and relational factors - intrinsic and externalthat influence how to effectively build a transdisciplinary team and co-produce rigorous scientific knowledge (Table 1). Several factors stand out. In terms of project structure and team composition, proper mechanisms to foster knowledge integration-such as face-toface dialogue, frequent interactions, cross-cultural communication, and spatial proximity - are necessary to enable the trust and communication required to meaningfully co-produce data, claims, and results (Carew and Wickson, 2010; Hegger et al, 2012; Lahsen and Nobre, 2014; Stokols et al., 2008; Romero-Lankao et al., 2013). Social learning - through the integration of different actors and reflexive, iterative research practice - is also considered a hallmark of successful transdisciplinary efforts (Cheruvelil et al., 2014; Hadorn et al; Fiore et al., 2010; Stokols et al., 2008; Pohl and Haborn 2008). Even in projects involving prominent science studies scholars, the broader 
structural challenges associated with power relations (internal and external), existing routines and incentives, embedded assumptions about how to conduct good science, and the desire to achieve integration still exert a sizeable influence on how transdisciplinary research is conceived and conducted (e.g. Donaldson et al, 2013; Lane et al, 2011; Whatmore and Landström, 2011).

In addition to the fundamental alchemy of team science, research on transdisciplinarity is replete with propositions on how to achieve a shared conceptual framework on issues and how to bridge boundaries - methodological, epistemological, organizational, and personal (Cash et al., 2003; Hegger et al., 2012; Hoppe et al., 2013; Jeffrey, 2003). Integration, in these studies, is largely seen as an epistemological barrier: since effective mainstreaming of climate change adaptation relies on comprehensive knowledge sharing between multiple stakeholders (Stott and Huq, 2014), identifying the right object of study is perceived as necessary to bridge diverse knowledge systems and communities.

Table 1. Organizational factors shaping transdisciplinary science.

\begin{tabular}{|c|c|}
\hline Factor & Characteristics \\
\hline \multicolumn{2}{|l|}{ Structural } \\
\hline $\begin{array}{l}\text { Clear expectation of } \\
\text { transdisciplinarity }\end{array}$ & $\begin{array}{l}\text { Cooperative policies that facilitate exchange; institutional } \\
\text { mandates; catalysts for integration; capacity building, and } \\
\text { memory }\end{array}$ \\
\hline $\begin{array}{l}\text { Appropriate scale and } \\
\text { magnitude }\end{array}$ & Identify the locus of problem and timeline for collaboration \\
\hline Funding and capital & $\begin{array}{l}\text { Continuity of funding; availability of labor, capital, and } \\
\text { organizational resources }\end{array}$ \\
\hline Spatial proximity & Face-to-face dialogue, interactive research processes \\
\hline Reward structures & $\begin{array}{l}\text { Influence of work policies (e.g. tenure and promotion); } \\
\text { compensation for labor; career stage }\end{array}$ \\
\hline $\begin{array}{l}\text { Problem identification } \\
\text { and structuring }\end{array}$ & $\begin{array}{l}\text { Clear common goals; "front loading" of social sciences and } \\
\text { humanities, identifying the right object of study }\end{array}$ \\
\hline \multicolumn{2}{|l|}{ Compositional } \\
\hline Stakeholder involvement & $\begin{array}{l}\text { Early engagement with stakeholders; careful selection of } \\
\text { collaborators }\end{array}$ \\
\hline Motivations & $\begin{array}{l}\text { Individuals with formal experience or training in } \\
\text { transdisciplinary research; basic vs. applied science }\end{array}$ \\
\hline Active management & $\begin{array}{l}\text { Democratic leadership; facilitation and mentorship; fair } \\
\text { allocation of responsibilities; conflict resolution }\end{array}$ \\
\hline $\begin{array}{l}\text { Standardization of } \\
\text { methods and data }\end{array}$ & $\begin{array}{l}\text { Appropriate infrastructure, resources, and data support; } \\
\text { discussion of intellectual rights and data security }\end{array}$ \\
\hline Diversity & $\begin{array}{l}\text { Diversity of team members according to ethnicity, gender, } \\
\text { discipline, function }\end{array}$ \\
\hline
\end{tabular}




\begin{tabular}{|l|l|}
\hline Cognitive and Relational & \\
\hline Trust & Credibility, interdependence, faith in others \\
\hline $\begin{array}{l}\text { Frequent and effective } \\
\text { communication }\end{array}$ & Updates, information sharing, shared concepts \\
\hline Social learning & $\begin{array}{l}\text { Recursive research design; flexibility to adapt to new tasks } \\
\text { and goals }\end{array}$ \\
\hline
\end{tabular}

Note: Factors were compiled by a comprehensive review of 60 papers on transdisciplinary research. For explication of factors, see Chompalov and Shrum (1999); Huutoniemi et al. (2010); Lang et al. (2012); Jahn et al. (2012); Vanasupa et al (2014).

But is knowledge integration merely an organizational or epistemic issue? Is transdisciplinary science achieved simply by assembling the 'right' object, method or team? As the next section explains, science studies scholars and political theorists have begun to frame integration as an ontological issue: made manifest in research practices oriented towards the generation of hybrid or relational objects (Barry and Born, 2013); in cases when problems resist efforts at disciplinary partitioning into natural and social fractions (Barry and Born, 2013); as a form of erasing difference among conflicting ways of knowing within team science (Reich and Reich, 2006); as well as means of depoliticizing science and foreclosing socio-environmental possibilities (Goeminne, 2012).

\section{Integration as ontological politics}

Science studies scholars have raised important questions about the central tenets of the scientific community, perhaps most notably the validity of the nature-culture dichotomy - a defining characteristic of the Western scientific worldview. The lines of demarcation between 'nature' and 'culture' are more often than not fuzzy because scientific practices are embedded in, and keep producing, hybrid 'socialnatures' (Callon 1986; Haraway 2007; Latour 1993, 2004). Among approaches in science studies, ActorNetwork Theory (ANT) has been particularly influential. ANT scholars examine how networks of human and nonhuman actors enable particular truth claims, enact different worlds, and give them meaning (Callon, 1986; Latour, 1987, 2005; Law and Hassard, 1999; Davis and Zanotti, 2014). As Latour states (2014, p.14):

As long as they act, agents have meaning. This is why such meaning may be continued, pursued, captured, translated, morphed into speech. Which does not mean that "everything in the world is a matter of discourse", but rather that any possibility for discourse is due to the presence of agents in search of their existence.

The word "agents" here refers to human and also nonhuman "actants," such as animals, weather patterns, or ideas, which Latour argues have the potential to alter the course of events.

Moreover, different ways of knowing do not simply constitute different perspectives on a common material world - the cultural relativistic position - but are actively constitutive of different worlds (Blaser, 2013; Escobar, 2007; Kohn, 2013; Strathern, 2004; Viveiros de Castro, 2011). Compositionism, suggests Latour (2010: 474), "takes up the task of building a common world...built from utterly heterogeneous 
parts that will never make a whole, but at best a fragile, revisable and diverse composite material." Likewise, knowledge production about climate change represents the progressive and necessarily partial composition of a common world, a fully political process that decides what can or cannot be discussed (Latour, 2010: 476).

Moreover, the process of producing knowledge to solve societal problemsarguably the core goal of transdisciplinary research - also involves mechanisms of inclusion/exclusion as scientists and non-scientists frame climate change adaptation according to what matters to them. For Chantal Mouffe (2005), there is a clear difference between the politics of making decisions about alternative policy options, and the pluralistic (antagonistic) conditions within which these choices are made, which she calls 'the political'. According to Mouffe, antagonism is constitutive of human societies and the formation of all social orders. "In the domain of collective identifications, where what is in question is the creation of a 'we' by the delimitation of a 'them', the possibility always exists that this we/them relation will turn into a relation of the friend/enemy types" (Mouffe, 2005: 2). In the context of climate change adaptation and transdisciplinary science, the notion of 'the political' suggests that we should understand integration as an exclusionary practice, which establishes boundaries between what knowledge claims are internalized from what knowledge claims are externalized. Differentiated matters of concern become factual claims deliberately and carefully composed through practices of production, reduction, negotiation, translation, amplification, circulation, and the endurance of claims through what Latour (1987) calls 'trials of strength'. As such, the politics of transdisciplinary climate change adaptation research represents an ongoing process of composition of contingent practices and discourses mediated by diverse actor-networks.

Empirical studies of the 'ontological politics' of transdisciplinary practices are limited because "much interdisciplinary research seems to proceed from the assumption that synthesis is desirable, that a new integrated perspective can be found on a singular object, if only the right object can be identified" (Donaldson et al., 2010). As John Law (2004) points out, science has an understandable tendency to ignore the messiness of discursive practices and objects and reduce the heterogeneity or multiplicity of material objects to a singular reality. To paraphrase Annemarie Mol (1999), a single person may understand climate change as different and sometimes irreconcilable objects of concern, and none of these are social constructions of which only one has emerged from his/her past experiences - these matters of concern emerged from different points his/her history, but none of them has vanished. This is an important point because, "beneath surface impressions of singular objects, there are myriad practices which to the outside observer (and even to those immersed in those practices) appear to be trained on the same object but which are, in fact, enacting subtly different 'realities' (or 'goods' if we want to capture the normative dimension)" (West, 2012, p. 424). Thus from an 'ontological politics' standpoint, when the issue to be addressed by transdisciplinary research is represents different matters of concern, that may be because different researchers are presenting not differing perspectives, but different, partially connected objects. By considering the ontological dimensions of the 'messy' practices of transdisciplinary research, the whole range of objects that are involved in climate change adaptation is brought into focus (Donaldson et al., 2010). 
By way of example, consider efforts by the Intergovernmental Panel on Climate Change (IPCC) to integrate knowledge, which is driven by a concern for homogeneity, simulation, and prediction (Goeminne, 2012), and hence the overwhelming focus on greenhouse gas mitigation, global circulation models, and forecasting impacts (Castree et al., 2014; Demeritt, 2001; Swyngedouw, 2010; Edwards, 2010). The IPCC is composed of alliances, competition, and conflict - as the so-called 'climategate' controversy so clearly illustrated (Goeminne, 2013) - and the process of laying claim to objectivity is relational and structured by processes of inclusion and exclusion, differentiating between what is taken into account and what is not (Goeminne, 2012). Yet, scientific and technocratic attempts at imposing a consensus on knowledge integration to support evidence-based policy-making poses the risk of obscuring the necessary political work of composing a common world, which may open (or shut out) different pathways of societal development.

Building on the notion of ontological friction as productive, rather than something to be erased or 'bridged' through joint knowledge production, in the next section we discuss alternative models of transdisciplinary research that foster knowledge coproduction by drawing upon antagonistic ways of knowing. In line with Braun (2009: 31 ), we direct attention to new modes of composing transdisciplinary environmental science, toward the development of "institutional spaces and procedures that allow us to work through, in an agonistic matter, how this composition of common worlds should proceed."

\section{Alternative models}

The models explored below represent three different approaches that could be utilized in research on climate change adaptation. The selected approaches are unique in that that do not seek a unified methodology, theory, or set of shared epistemological assumptions. Each alternative has its limitations, since no single approach to transdisciplinary knowledge production is immune to power dynamics, and no single model suits all settings and contexts. Nevertheless, we chose these approaches because they exhibit three core principles: experimentation with different ways of knowing; the avoidance of using Western science as the benchmark to judge or align all other forms of knowing and adapting to climate change; and being attentive to 'uncomfortable' ways of knowing. Following a brief description of each of these models, we illustrate their application in the context of transdisciplinary research in climate change adaptation in the Arctic, focusing on alternative means of cross-boundary engagement with indigenous ways of knowing (Bates, 2007).

\subsection{Triangulation}

In Taking Complexity Seriously, Emery Roe (1998) argues for triangulation in environmental science and policy making: the idea that policy issues involving high levels of uncertainty, complexity, incompleteness, and conflict - particularly those pivoting on science, technology and the environment - should be analyzed and addressed using a plurality of theories and methodologies. For Roe (2000), complexity refers to the increased number of elements in a system, their functional differentiation and their interdependence. In contrast to holistic approaches that advocate knowledge integration as the means to address complex problems, Roe argued that taking complexity seriously means engaging in case-by-case analysis, prioritization, and decision-making under 
persistent uncertainty. Above all, decision-making in the context of complexity and uncertainty should be experimental and allow for rapid adaptive responses to surprises, the testing of competing approaches, and the building of experiential knowledge (Roe, 1998). The call for active public experimentation to address complex environmental problems is increasingly echoed across disciplines (Gross, 2010; Latour, 2004; Sabel, 2012; Whatmore and Landström, 2011).

The triangulation approach is reminiscent of early twentieth century American pragmatists, such as John Dewey, who - drawing on parallel discoveries and technological innovation in the sciences_-argued for an experimental approach to politics, development, and the social sciences (Dewey, 1930).

If ideas, meanings, conceptions, notions, theories, systems are instrumental to an active reorganization of the given environment, to a removal of some trouble and perplexity, then the test of their validity and value lies in accomplishing this work. If they succeed in their office, they are reliable, sound, valid, good, true. If they fail to clear up uncertainty and evil when they are acted upon then they are false. (Dewey, 2004[1920]: 90)

From a Deweyan perspective, the dynamic relationship between knowledge production and policy-making is often construed as "ends-in-views" or plans. When acted upon, these plans "structure" the assembling and evaluation of our common world. That is, "end-in-views" may be experientially evaluated as "if-then" proposals: "if we do such and such actions applying policy X, we believe such and such results will occur" (Dewey, 1939: 90). Moreover, as Hilary and Ruth Anna Putnam (1994: 216) have pointed out, Dewey argued that democracy is the precondition for the application of intelligence to the solution of social problems. Thus, pragmatism explicitly "challenges the tendency to frame scientific reliability, social relevance, and social legitimacy as distinct requirements on knowledge, to be traded off against one another" and instead emphasizes "the role of collaborative deliberation and practice knowledge generated through processes of social innovation and experimentation" (Popa et al, 2015: 10). Despite Roe's advocacy for the "scientific method" of triangulation, his approach does not imply the use of any particular privileged epistemological and methodological norms. Rather, in line with Deweyan pragmatism, the triangulation approach emphasizes the inclusion of different 'publics' - those who are most affected by problematic issues - in the production of knowledge and corresponding decisions.

\subsection{The multiple evidence-base approach}

In contrast to triangulation, in which the relevance and utility of different knowledge systems is assessed through experimentation, the 'multiple evidence-base approach' (MEBA) seeks to connect diverse knowledge systems through facilitating parallel lines of indigenous, local and scientific inquiry (Tengö et al, 2014). MEBA suggests that the

quality and validity of research results are assessed within each knowledge system, with a view to developing complementarity and synergy. Mindful of the contradictions that may exist across diverse knowledge systems, Tengö et al (2014: 585) suggest:

In processing the enriched picture, conflicting or contradictory evidence should not be neglected or concealed but accepted as such since there is some knowledge and information that will remain incompatible. The diversity of perspectives can benefit further knowledge generation as well as decision-making. The enriched picture creates an opportunity for a culturally informed appraisal of scientific knowledge 
and practice so as to differentiate between elements that could be recognized as 'universal' or shared among knowledge systems as opposed to 'relative' or unique to a specific knowledge system.

Accordingly, MEBA seeks to widen the scope, depth and value of environmental assessments, proposing a path towards the cross-fertilization of ideas and the coproduction of complementary knowledge. Although this model is tied to the regulative ideal of converging knowledge systems, MEBA emphasizes the diversity of different knowledge systems rather than seeking to reconcile them through the integration of data, methods, results, or claims. In other words, where complementarity and synergy does not exist between different knowledge systems, MEBA frames diversity and conflict among different systems as valuable and productive, especially in the effort to generate new insights or further study ideas.

In keeping with the tradition of 'co-management' (Nadasdy, 2005) and 'adaptive management' (Folke et al., 2005), MEBA seeks to include indigenous traditional ecological knowledge (TEK) to inform ecosystem governance. As Paul Nadasdy (2005) notes in reference to co-management boards in northern Canada, inviting indigenous people to participate in these governance arrangements may appear empowering, however the important question here is not how much people are empowered but rather what it is that they are empowered to do. The risk is that participants are constrained by (methodological, epistemological, and institutional) rules they have no power to change (Rosendalh et al., 2014). While not immune to the risks of tokenism, informal hierarchies, and disciplinary policing (Reich and Reich (2006), MEBA nevertheless tries to mitigate such risks by emphasizing that each way of knowing should be assessed with internal criteria and not just external referents.

\subsection{Scenario building}

In contrast to the approaches described above, our last example is more challenging in that it deliberately seeks out knowledge that is disquieting, uncomfortable, and potentially disruptive, as a means to envision and prepare for the unexpected consequences of our current practices and anthropogenic trajectories. Couched within 'futures research'-or "the systematic study of what might be" (Gordon, 1992) - this approach is especially concerned with unanticipated system effects and those parts of the future that escape prediction: "those [futures] that come to an individual or collective decision-maker independent of intention, and that cannot be influenced ex-ante" (Ramírez and Ravetz, 2011: 478). The authors term these 'feral futures': futures that were thought to be predictable given previous experiences, best available science, planning and riskmanagement techniques, but that have deviated from expectations and are essentially uncontrollable and potentially irreversible (Ramírez and Ravetz, 2011). The qualifier 'feral' indicates a future that once was thought of as domesticated through human agency, but that has unexpectedly become 'wild' and unknowable. According to Ramírez and Ravetz (2011: 480):

All feral futures are anthropogenic, as it is human intervention that does the taming in the first place; and then humans weaken, re-locate, damage, or even destroy the domesticating system. More generally, parts of the society-technology-nature system which had been thought to have been tamed, such as global food and water systems or biotic disease, now show signs that they might be going out of control through human intervention and are hence in a situation where they could become 
feral...In feral futures recognition that continuing risk-based interventions may be contributing to unknowable unfurling paths of danger is required, but difficult to obtain.

For Ramírez and Ravetz (2011), the discovery of 'feral futures' is critical in the early stages, so that their potential developments can be arrested and their potential effects mitigated or even transformed. Counterintuitively (from a western scientific perspective), Ramírez and Ravetz (2011) propose 'unlearning' by becoming reflexive about our assumptions, practices and belief systems - which involve analyzing the power and discourse of the present and how it emerged from a contingent integration of various ways of knowing.

To do so, scenarios are used to imagine and forecast how things might become feral, and the conditions necessary to arrest these possibilities as early as possible through corrective and mitigative actions. Conventional risk analyses are of little use here, since Ramírez and Ravetz (2011) argue these analyses actually contribute to the drivers that make futures feral. For to Ramírez and Ravetz (2011), the embrace of 'uncomfortable knowledge' is in fact extremely useful in future scenario planning:

For situations in which the mere possibility of a feral future exists, we advocate scenario work which seeks to extend the peer review community by seriously considering that which had hitherto been unwelcome, politically incorrect, destabilizing, and radical, along with that which questions established categories, labels, connotations, roles, sources of legitimacy, and power relations. While it many appear naïve to attempt to 'co-opt the enemy' of the established order through such scenario work in order to enhance the quality of inquiries about feral futures, we believe that failing to do so has dangerous consequences in the preservation of 'ignorance of ignorance' (Ramírez and Ravetz, 2011: 482). Similarly to merging art and design in foresight research (Selin, 2014), imagining feral futures requires attention to power, inclusiveness, trade-offs and efficacy.

What does it mean to implement scenario work in transdisciplinary science? Ramírez and Ravetz (2011) draw on Zen and Aesthetics to help researchers let go of labels and distinctions that are attached to common perceptions of futures, including norms of understanding, conception, experience, and predictability, and invite knowledge and actions that move beyond a priori categories. Along with others (Selin, 2014; Brown, 2014; Barrett, 2013), Ramírez and Ravetz (2011) argue that we must be attuned to 'gut feelings' and intuitions about the future; resist initial judgments regarding radically different or uncomfortable knowledge; and 'surf the boundary' between different ways of knowing (MacLellan, 2010). Equipped with these skills, researchers" "sensitivities will become far more liberated from the attachments of judgments, more ready to question and even criticize established frames (including ones' own), and so be better placed to identify early signs of contingencies that would otherwise be too frightening or threatening to contemplate, or of which [we] may even remain conceptually incapable" (Ramírez and Ravetz, 2011: 484). While a feral futures approach shares with the earlier notion of anticipatory governance (Guston, 2014) the goals of building capacity in foresight and engagement, it does not seek an integrated end product.

\subsection{Illustrative case}

By way of illustration, consider Bates' (2007) insightful comparison between Inuit ways of knowing and adapting to environmental change and Western scientific approaches to 
climate change adaptation planning, modeling, and uncertainty. Similar to other huntergatherer societies, the Inuit animistic ontology makes possible different kinds of relationships between humans and non-humans, and, in turn, how they plan for climate change (Ingold, 2000). For the Inuit, thoughts and words have inherent agency, which explains their reticence to make predictions of climate change impacts, since "careless words and in particular definitive statements that fail to recognize the inherent uncertainty of the world, are dangerous" (Bates, 2007: 94). Indeed, for the Inuit, "negative thoughts about the future may actualize that scenario, creating the bleak situation described" (Bates, 2007: 94). In this way, the Inuit appear to accept and embrace uncertainty and change, fundamental characteristics of life in the Arctic, and focus on in-depth knowledge of the present coupled with skills of improvisation to engender the flexibility needed to respond to situations as they arise.

While the Inuit actively predict and plan for the future on seasonal and yearly bases, Bates cautions against drawing close similarities between Inuit prediction and planning activities with Western scientific understandings of adaptation. In so doing, "such attempts can delegitimize Inuit ways of knowing the future, by effectively setting Western science as a benchmark by which Inuit knowledge is judged, thus reducing the likelihood of effective collaboration between Inuit and Western researchers in environmental management" (Bates, 2007:87). In fact, Inuit philosophies about the future, long-term planning and predictions challenge the basic premise of Western scientific approaches to climate change adaptation: that long-term forecasting is essential to effective decision-making. It is instructive to note that several studies have suggested that indigenous people in the Arctic indeed have the necessary knowledge and skills to adapt to climate change (Berkes and Joly, 2001; Forbes et al., 2009). In short, the Inuit/Western science example illustrates the fundamental challenges of 'integrating' knowledge among different ontological traditions and communities (Bates, 2007).

To mitigate risk that future paths of development in the Arctic simply reproduce the status quo of vested interests, Roe's (1998) triangulation approach highlights the need for a "case-by-case" process of knowledge co-production and application tailored to specific contexts. As Popa et al (2015: 3) notes,

Without an explicit reflexive dimension, transdisciplinary research is confronted with the risk of either being reduced to formal social consultation, with no real impact in how knowledge is generated or integrated into policy-making, or evolving towards a politicized form of 'democratic science' in which epistemic aspects are subordinated to procedures of social legitimization, in such a situation the explanatory shortcomings, lack of clear normative orientation and perceived 'hidden agendas' of research can severely undermine public trust and the legitimacy of scientific knowledge, weakening its capacity to inform and guide policy-making.

Indeed, Roe's triangulation approach seeks to make transparent the antagonism between different ways of knowing such as the Inuit/Western science example in a 'realpolitik' context of deciding what paths to pursue, knowing all the while that the hard choices performed in such societal experiments are provisional and may unfold in unexpected ways. In the context of climate change adaptation, Roe's triangulation approach reminds us that what might be interpreted as "matters of fact"- - such as the notion that only 
human beings have agency — may actually be "matters of concern" with political implications (Latour, 1987; see also Goeminne, 2012).

Using MEBA suggests a need to assess the Inuit's in-depth knowledge of the present, coupled with their skills of improvisation within their animistic knowledge system, and avoid using Western science as the standard of assessment. This may reveal that "ways of knowing that would normally have been considered not valid, irrational or not useful, begin to be seen not only as legitimate, but immensely valuable for personal and socio-ecological decision-making" (Barrett, 2013:180). Similarly, anthropologist Tim Ingold (2010: 42) goes a step further than calling for a reflexive stance towards Western science. He suggests that we should reverse the common order of primacy of science over hunter-gatherers' cosmology, and follow the lead of hunter-gatherers in taking the human condition to be that of a being immersed from the start, like other creatures, in an active, practical and perceptual engagement with constituents of a common world. Taking a cue from Ernesto Laclau's poststructuralist discourse theory, Panizza and Miorelli (2013, p.305) make an insightful point about the politics involved in such discursive practices:

Discourse is not a neutral medium of signs and symbols that simply connects ideas and objects. Discursive practices involve binding together heterogeneous ideational elements that have no necessary logical relations among themselves and were not previously thought of as belonging together in a relational ensemble. Thus, discursive practices enable actors to experience and think about the world in certain ways. In doing so, discourses crystallize power struggles and set the parameters of what is sayable and indeed thinkable in a given social order.

Finally, the scenarios approach enables the exploration of radically different futures in the Arctic and elsewhere. In response to Ramírez and Ravetz's (2011) call to seek out 'uncomfortable' knowledge in scenario building, we refer to Barrett (2013) "transrational ways of knowing", which include learning from dreams, which for many hunter-gatherer societies are formative experiences embodying valuable knowledge (Ingold, 2010:99; Barrett, 2013); we might draw upon artistic inspiration as a means to 'tap into' troubling emotions (Selin, 2014) or visualize aspects of environmental change not observable through immediate scientific means (e.g., Chasing Ice, a film by James Balog); or we might imagine how relating to animals as persons might affect how we manage natural resources in the far north (Bates, 2007). Similarly, Brown (2014) promotes the practice of 'utopian thinking', in which fostering introspection, empathy, material, social, ethical, aesthetic and sympathetic knowing might create hopeful visions of a world not so divided. Indeed, Freitag (2014) and Barrett (2013) remind us that we should not forget the ethical reasons for taking different ways of knowing seriously. The fact that scenario building is a relational practice involving humans (and potentially nonhumans, as is the case in animistic ontologies) raises concerns not only about the political implications of exclusionary practices, conflicting knowledge systems and power dynamics, but also the ethical implications of these relational practices for composing a common world.

\section{Conclusion}

In this article, we have argued that the 'integration imperative' in transdisciplinary environmental science masks the ontological politics of scientific knowledge - including the friction, antagonism, and power inherent in knowledge co-production - and in turn restricts alternative and experimental ways of understanding and adapting to climate 
change. What the three alternative models of transdisciplinary research described above - namely triangulation/experimentation, the multiple-evidence based approach, and scenario building — offer are potential roadmaps to doing transdisciplinary environmental science in a way that spotlights (and even draws strength from) the ontological politics of assembling different ways of knowing and adapting to climate change. The triangulation approach offers a means to iteratively and experimentally compose a common world, while MEBA reminds us that Western science should not be the final arbiter, but rather conceived as one among many knowledge systems. Finally, when faced with unknowns, such as future trajectories that we thought were under control but that our very efforts at managing have caused them to go feral, we need to attend to ways of perceiving our environment and acting within it that seek to connect to that which was externalized from our common world - thus engaging in the political reconfiguration of the present social order.

To be clear, we are not arguing against transdisciplinary science, or that it is a flawed or defective approach to environmental research. We actively teach in interdisciplinary academic units and contribute to transdisciplinary research projects. Rather, we caution that the laudable goal to craft diverse research initiatives and collaborations introduces as many new challenges (such as irreconcilable knowledge systems or worldviews) as it attempts to mitigate. Transdisciplinarity, in short, cannot be a precursor for integration; instead, transdisciplinary environmental science must recognize and value difference as much as it strives to produce policy-relevant knowledge.

This point is especially important given the imbalance of power still present in transdisciplinary environmental science, particularly regarding climate change (Castree et al, 2014). Calls for useful and integrative knowledge in global change research have coincided with narrow conceptions of social science and poor inclusion of the humanities and stakeholders (Lahsen, 2010; Turnhout et al., 2012; Barnes, 2013; Castree et al, 2014; Carey et al, 2014; Beck et al., 2014). Making transdisciplinarity work is not only about getting the team and object of concern 'right', but also about attending to how knowledge and power are often unequally available, differentially composed, and fundamental to developing alternative pathways of understanding and response. If transdisciplinary collaboration is required to engage meaningfully with complex problems, and if focusing overly much on integration in a sense limits the import of transdisciplinary collaborations, then understanding the limits of the integrationist model, and looking for alternatives, is central to our ability to better deal with current and future problems.

\section{Acknowledgments}

We thank Dr. Paul Hirsch for his comments on the theoretical section of the article and for articulating the concluding sentence, which elegantly and succinctly captures the gist of our argument. We also thank Dr. Jim MacLellan and Dr. Matthew Hoffman for commenting on sections of an earlier draft of the manuscript. This research was funded by a Fulbright NEXUS Grant to Nicole Klenk and Katie Meehan, and also in part by a Social Science and Humanities Research Council Partnership Development Grant to Nicole Klenk. 


\section{References}

Adger, W.N., N.W. Arnell and E.L. Tompkins (2005) Successful adaptation to climate change across scale. Global Environmental Change 15: 77-86.

Amara, N., M. Ouimet., and R. Landry. (2004) New evidence on instrumental, conceptual, and symbolic utilization of university research in government agencies. Science Communication 26: 75-106.

Ayre, M. and R. Nettle (2015) Doing integration in catchment management research: Insights into a dynamic learning process. Environmental Science \& Policy 47: 1831.

Barnes, J., M. Dove, M. Lahsen, A. Mathews, P. McElwee, R. McIntosh, F. Moore, J. O'Reilley, B. Orlove, R. Puri, H. Weiss and K. Yager. (2013) Contribution of anthropology to the study of climate change. Nature Climate Change 3: 541-544.

Barrett, M.J. (2013) Enabling hybrid space: epistemological diversity in socio-ecological problem-solving. Policy Science 46: 179-97.

Barry, A., and G. Born. (2013) "Interdisciplinarity: Reconfigurations of the social and natural sciences.” In A. Barry and G. Born, eds. Interdisciplinarity:

Reconfigurations of the Social and Natural Sciences, 1-56, Routledge, London.

Bates, P. (2007) Inuit and scientific philosophies about planning, prediction, and uncertainty. Arctic Anthropology 44(2): 87-100.

Beck, S., M. Borie, J. Chilvers, A. Esguerra, K. Heubach, M. Hulme, R. Lidskog, E. Lovbrand, E. Marquard, C. Miller, T. Nadim, C. Nesshover, J. Settele, E. Turnhout, E. Vasileiadou, C. Gorg. (2014) Towards a reflexive turn in the governance of global environmental expertise. The cases of the IPCC and IPBES. Gaia 23(2): 80-87.

Berkes, F. and D. Jolly. (2001) Adapting to Climate Change: Social-Ecological Resilience in a Canadian Western Arctic Community. Ecology and Society 5(2): 18. Online: http://www.ecologyandsociety.org/vol5/iss2/art18/

Blaser, M. (2013) Ontological Conflicts and the Stories of Peoples in Spite of Europe: Toward a Conversation on Political Ontology. Current Anthropology 54(5): 547568.

Boon, W.P.C., M.H. Maryse, and J. Perenboom. (2014) Balancing divergence and convergence in transdisciplinary research teams. Environmental Science \& Policy 40: 57-68.

Bozeman, B., and C. Boardman. (2014) Research collaboration and Team Science. SpringerBriefs in Entrepreneurship and Innovation. DOI 10.1007/978-3-31906468-0 1

Braun, B. (2009) Nature. in A companion to environmental geography, N. Casttree, D. Demeritt, D.Liverman and B. Rhoads (Eds.), 19-36. London, Blackwell.

Brown, V.A. (2014) Utopian thinking and the collective mind: beyond transdisciplinarity. Futures: In Press. Doi:10.1016/j.futures.2014.11.004

Brugnach, M., and H. Ingram. (2012) Ambiguity: the challenges of knowing and deciding together. Environmental Science \& Policy 15(1): 60-71.

Etzkowitz, H., and L. Leydesdorff. (2000) The dynamics of innovation: from national systems and "mode 2 " to a triple helix of university-industry-government relations. Research Policy 29: 109-123.

Law, J. and J. Hassard. (1999) Actor-Network Theory and After. Blackwell, Oxford. 
Callon, M. (1986) "Some Elements of a Sociology of Translation: Domestication of the Scallops and the Fishermen of St. Brieuc Bay." In John Law, ed. Power, Action and Belief: A New Sociology of Knowledge?, 196-223. Routledge. London.

Cash, D.W., W.C. Clark, F. Alcock, N.M. Dickson, N. Eckley, D.H. Gutson, J. Jäger, and R.B. Mitchell. (2003) Knowledge systems for sustainable development. Proceedings of the National Academy of Sciences 100(14): 8086-8091.

Carey, M., L.C. James, and H.A. Fuller. (2014) A new social contract for the IPCC. Nature Climate Change 4: 1038-1039.

Castree, N., W.A. Adams, J. Barry, D. Brockington, B. Büscher, E. Corbera, D. Demeritt, R. Duffy, U. Felt, K. Neves, P. Newell, L. Pellizzoni, K. Rigby, P. Robbins, L. Robin, DB. Rose, A. Ross, D. Scholsberg, S. Sörlin, P. West, M. Whitehead, and B. Wynne. (2014) Changing the intellectual climate. Nature Climate Change 4: 763-768.

Chompalov, I. and W. Shrum. (1999) Institutional collaboration in science: a typology of technological practice. Science Technology and Human Values 24(3): 338-372.

Davis, R. and L. Zanotti. (2014) Science, conservation and the production of nature. Anthropological Quarterly 87(3): 601-611.

Demeritt, D. (2001) The construction of global warming and the politics of science. Annals of the Association of American Geographers 91(2): 307-337.

Descola, P. (2013) Beyond Nature and Culture. University of Chicago Press, Chicago.

Dewey, J. (2004 [1920]) Reconstruction in Philosophy. Dover Publications, Mineola, NY.

Dewey, J. (1930) Individualism, old and new. New York: Minton, Balch \& Co.

Dewey, J. (1939) Theory of Valuation. The University of Chicago Press, Chicago.

Dilling, L. and M.C. Lemos. (2011) Creating usable science: opportunities and constraints for climate knowledge use and their implications for science policy. Global Environmental Change 21(2): 680-689.

Donaldson, A., S. Lane, N. Ward, and S. Whatmore. (2013) Overflowing with issues: following the political trajectories of flooding. Environment and Planning C: Government and Policy 31: 603-618.

Edwards, P. (2010) A Vast Machine: Computer Models, Climate Data and the Politics of Global Warming. Cambridge (MA) \& London, MIT Press.

Escobar, A. (2007) The 'Ontological Turn' in Social Theory: A Commentary on 'Human Geography Without Scale' by Sallie Marston, John Paul Jones III and Keith Woodward. Transactions of the Institute of British Geographers 32(1): 106-111.

Fitzgerald, D., M.M. Littlefield, K.J. Knudsen, J. Tonks, and M.J. Dietz. (2014) Ambivalence, equivocation and the politics of experimental knowledge: A transdisciplinary neuroscience encounter. Social Studies of Science 44(5): 701721.

Folke, C., T. Hahn, P. Olsson, J. Norberg. (2005) Adaptive governance of socialecological systems. Annual Reviews of Environment and Resources 30: 441-473.

Forbes, B.C., F. Stammler, T. Kumpula, N. Meschtyb, A. Pajunen, and E. Kaarlejärvi. (2009). High resilience in the Yamal-Nenets social-ecological system, West Siberian Arctic, Russia. Proceedings of the National Academy of Sciences 106(52): 22041-22-48. 
Freitag, A. (2014). The promise and solutions from increasing diversity in ways of kniwing: Educational lessons from meteorology, ethnobotany, and systems ecology. Environment and Society: Advances in Research 5(1): 28-46.

Gibbons, M., C. Limoges, H. Nowotny, S. Schwartzman, P. Scott, and M. Trow. (1994) The New Production of Knowledge: The Dynamics of Science and Research in Contemporary Societies. Thousand Oaks, CA, Sage.

Goeminne, G. (2012) Lost in translation: Climate denial and the return of the political. Global Environmental Politics 12: 1-8.

Goeminne, G. (2013) Does the climate need consensus?: The politics of climate change revisited. Symploke 21(1-2): 147-161.

Gordon, T.J. (1992) The methods of futures research. Annals of the American Academy of Political and Social Science 522: 25-35.

Groß, M. (2010). Ignorance and Surprise: Science, Society and Ecological Design. MIT Press, Cambridge, MA.

Groß, M. and M. Stauffacher. (2014) Transdisciplinary environmental science: problemoriented projects and strategic research programs. Interdisciplinary Science Reviews 39(4): 299-306.

Guston, D.H. (2014) Understanding 'anticipatory governance'. Social Studies of Science 44(2): 218-242.

Hadorn, G.H., C. Pohl, and G. Bammer. Solving problems through transdisciplinary research. In Julie Thompson Klein and Carl Mitcham (eds.), The Handbook of Interdisciplinarity. Oup Oxford. 431-52.

Haraway, D.J. (2007) When Species Meet. University of Minnesota Press, Minneapolis.

Hegger, D., M. Lamers, A. Van Zeigl-Rozema and C. Dieperink. (2012) Conceptualizing joint knowledge production in regional climate change adaptation projects: success conditions and levers for action. Environmental Science \& Policy 18: 5265.

Hoppe, R., A. Wesselink, and R. Cairns. (2013) Lost in the problem: the role of boundary organisations in the governance of climate change. WIREs Climate Change 4: 283-300.

Ingold, T. (2000) The Perception of the Environment. New York, Routledge.

Iyalomhe, F., A. Jensen, A. Critto, and A. Marcomini. (2013) The science-policy interface for climate change adaptation: the contribution of communities of practice theory. Environmental Policy and Governance 23(6): 368-380.

Jeffrey, P. (2003) Smoothing the waters: observations on the process of cross-disciplinary research collaboration. Social Studies of Science 33(4): 539-562.

Jepson, P., M. Barua and K. Buckingham. (2011) What is a conservation actor? Conservation \& Society 9: 229-235.

Kerstin, K. and K. Barth. (2014) Inter- and transdisciplinary research for planning climate change adaptation: the example of Santiago de Chile. Interdisciplinary Science Review 39(4): 360-375.

Kohn, E. (2013) How Forests Think: Toward an Ethnography Beyond the Human. University of California Press, Berkeley.

Lahsen, M. (2009) A science-policy interface in the global south: the politics of carbon sinks and science in Brazil. Climatic Change 97(1): 339-372. 
Lahsen, M. (2010) The social status of climate change knowledge: an editorial essay. WIREs Climate Change 1: 162-171.

Lahsen, M., R. Sanchez-Rodriguez, P. Romero Lankao, P. Dube, R. Leemas, O. Gaffney, M. Mirza, P. Pinho, B. Osman-Elasha, and M. Stafford Smith. (2010) Impacts, adaptation and vulnerability to global environmental change: challenges and pathways for an action-oriented research agenda for middle-income and lowincome countries. Current Opinion in Environmental Sustainability 2: 364-374.

Lane, S. N., N. Odoni, C. Landstrom, S.J. Whatmore, N. Ward, and S. Bradley. (2011) Doing flood risk science differently: an experiment in radical scientific method. Transactions of the Institute of British Geographers 36: 15-36.

Latour, B. (1987) Science in Action: How to Follow Scientists and Engineers through Society. Harvard University Press, Cambridge.

Latour, B. (1993) We Have Never Been Modern. Cambridge: Harvard University Press.

Latour, B. (2004) Politics of Nature: How to Bring the Sciences Back into Democracy. Harvard University Press, Cambridge.

Latour, B. (2005) Reassembling the Social: An Introduction to Actor-Network Theory. Oxford University Press, Oxford.

Latour, B. (2010) An attempt at a compositionalist manifesto. New Literary History 41: 471-490.

Latour, B. (2014) Agency at the time of the Anthropocene. New Literary History 45: 118.

Law, J. 2004. Organizing Modernity. Oxford, Blackwell.

Lyall, D., A. Bruce, and W. Marsen. (2011) Identifying key success factors in the quest for interdisciplinary knowledge. Available online: http:/www.esrc.ac.uk/myesrc/grants/RES-145-28-0002/outputs/read/ee7cdb39-f99b-45ca-b9de$408 \mathrm{f} 43$ eac5cc

Lynch, A.H., L. Tryhorn, and R. Abramson. (2008) Working at the boundary: facilitating interdisciplinarity in climate change adaptation research. Bulletin of the American Meteorological Society 89 169-179.

MacLellan, J.I. (2010) Boundary surfing the local-global dialectic. Presentation November $25^{\text {th }}$ at the University of Waterloo, Sustainability Governance Group, Ontario, Canada.

Maiello, A., C.V. Viegas, M. Frey, and J.L. Ribeiro. (2013) Public managers as catalysts of knowledge co-production? Investigating knowledge dynamics in local environmental policy. Environmental Science \& Policy 27: 141-150.

Mol, A. (1999) Ontological politics. A word and some questions. In J.Law and J. Hasard, (Eds.) Actor Network Theory and After. Oxford, Blackwell.

Mol, A. (2002) The Body Multiple: Ontology in Medical Practice. Duke University Press, Durham.

Mouffe, C. (2005) The Return of the Political. New York, Verso.

Murphy, D.J. (2014) Ecology of rule: Territorial assemblages and environmental governance in rural Mongolia. Anthropological Quarterly 87(3): 759-792.

Nadasdy, P. (2005) The anti-politics of TEK: The institutionalization of co-management discourse and practice. Anthropologica 47(2): 215-232.

Nowotny, H., P. Scott, and M. Gibbons. (2001) Re-Thinking Science: Knowledge and the Public in an Age of Uncertainty. Cambridge, Polity Press. 
Panizza, F. and R. Miorelli. (2013) Taking discourse seriously: discursive institutionalism and post-structuralist discourse theory. Polit. Stud. 61, 301-318.

Pohl, C., and G.H. Hadorn. (2008) Methodological challenges of transdisciplinary research. Natures Sciences Societies 16(2): 111-121.

Popa, F., M. Guillermin and T. Dedeurwaerdere. (2015). A pragmatist approach to TD in sustainability research: From complex systems theory to reflexive science.

Futures 65: 45-56.

Putnam, H. and R. A. Putnam (1994) "Dewey's Logic" in James Conant (ed.). Words and Life: Hilary Putnam. pp. 198-220.Harvard University Press, Cambridge, Massachusetts.

Rabinow, P, and G. Bennett. (2012) Designing Human Practices. An Experiment with Synthetic Biology. University of Chicago Press, Chicago.

Ramírez, R., and J. Ravetz. (2011) Feral Futures: Zen and Aesthetics. Futures 43(4): 478487.

Roe, E. (1998) Taking Complexity Seriously. Policy Analysis, Triangulation and Sustainable Development. Boston, Kluwer Academic Publishers.

Romero-Lankao, P., M. Borbor-Cordova, R. Abrutsky, G. Günther, E. Behrentz, L. Dawidowsky. (2013) ADAPTE: A tale of diverse teams coming together to do issue-driven interdisciplinary research. Environmental Science \& Policy 26: 2939.

Rosendalh, J., M.A. Zanella, S. Rist and J. Weigelt. (2014). Scientists' situated knowledge: strong objectivity in TD. Futures: In Press.

Doi:10.1016/j.futures.2014.10.011

Sabel, C. (2012) Dewey, democracy and Democratic experimentalism. Contemporary Pragmatism 9(2): 35-55.

Selin, C. (2014) Merging art and design in foresight: Making sense of Emerge. Futures: In Press. Doi:10.1016/j.futures.2014.12.006

Serrao-Neumann, S., G. Schuch, B. Harman, F. Crick, M. Sano, O. Sahin, R. van Staden, S. Baum, D. Low Choy. (2015) One human settlement: a transdisciplinary approach to climate change adaptation research. Futures 65: 97-109.

Star, S.L., and J.R. Griesemer. (1989) Institutional ecology, 'translations' and boundary objects: Amateurs and professionals in Berkeley's Museum of Vertebrate Zoology 1907-39 Social Studies of Science 19(3): 387-420.

Stott, C. and S. Huq. (2014) Knowledge flows in climate change adaptation: exploring friction between scales. Climate and Development 6(4): 382-387.

Strathern, M. (2004 [1991]) Partial Connections: Updated Edition. AltaMira Press, New York.

Swyngedouw, E. (2010) Apocalypse forever? Post-political populism and the specter of climate change. Theory, Culture \& Society 27 (2-3): 213-32.

Tengö, M., E.S. Bondizio, T. Elmqvist, P. Malmer, and M. Spierenburg. (2014) Connecting diverse knowledge systems for enhanced ecosystem governance: The multiple evidence based approach. Ambio 43: 579-591.

Turnhout, E., B. Bloomfield, M. Hulme, J. Vogel, B. Wynne. (2012) Listen to the voice of of experience. Nature Climate Change 488: 454-455.

Viveiros de Castro, E. (2011) Zeno and the Art of Anthropology: Of Lies, Beliefs, Paradoxes, and Other Truths. Common Knowledge 17(1): 128-145. 
West, K. (2012) Articulating discursive and materialist conceptions of practice in the logics approach to critical policy analysis. Critical Policy Studies 5(4): 414-433.

Whatmore, S.J. and C. Landström. (2011) Flood apprentices: an exercise in making things public. Economy and Society 40: 582-610 